Jerzy KUNIKOWSKI

Uniwersytet Przyrodniczo-Humanistyczny w Siedlcach ${ }^{1}$

Wydziat Nauk Spotecznych

jerzy.kunikowski@uph.edu.pl

https://orcid.org/0000-0003-4557-1010

https://doi.org/10.34739/dsd.2021.02.07

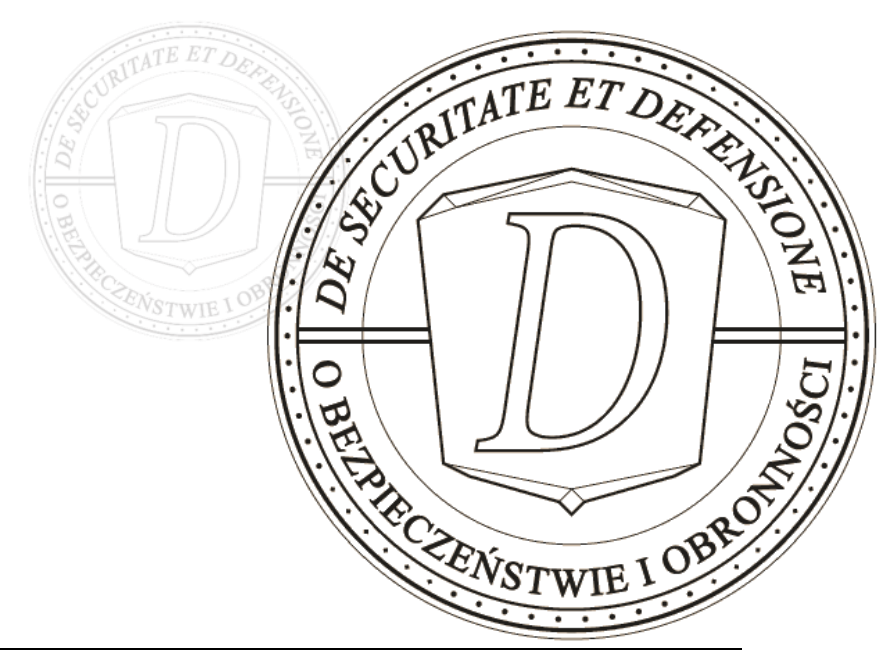

\title{
OBSZARY WYZWAŃ EDUKACJI DLA BEZPIECZEŃSTWA
}

\begin{abstract}
ABSTRAKT: Obserwowana od dłuższego czasu zmienność bliższego i dalszego otoczenia wymaga przygotowania poszczególnych podmiotów życia społecznego do radzenia sobie w sytuacjach zagrożeń, jest to niezwykle istotne ze względu na potrzebę zapewnienia bezpieczeństwa w wymiarze zarówno personalnym, jak i strukturalnym. Zadanie to jest możliwe, choć niewątpliwie niełatwe, jednak za sprawą edukacji, która ma na celu: dobro jednostki i jej kreatywność, samorealizację, szeroko rozumianą odpowiedzialność, a także umiejętności przystosowania się do zachowań w obliczu zagrożeń można wyposażyć społeczeństwo w wiedzę oraz umiejętności niezbędne do przeciwstawiania się pojawiającym się wyzwaniom. Autor dokonuje analizy wyzwań w obszarze edukacji dla bezpieczeństwa, wskazując na coraz bardziej poszerzający się jej zakres przedmiotowy.
\end{abstract}

SŁowA KLUCzowe: edukacja, wyzwania, zagrożenia, edukacja dla bezpieczeństwa

\section{AREAS OF CHALLENGES OF EDUCATION FOR SAFETY}

ABSTRACT: The variability of the closer and more distant environment, which has been observed for a long time, requires the preparation of individual entities of social life to cope with threatening situations, which is extremely important due to the need to ensure security in terms of both personnel and structure. This task is possible, although undoubtedly not easy, but thanks to education aimed at: the good of the individual and his creativity, self-fulfillment, broadly understood responsibility, as well as the ability to adapt to behavior in the face of threats, it is possible to equip society with the necessary knowledge and skills. to withstand emerging challenges. The author analyzes the challenges in the area of education for security, pointing to its increasingly expanding subject scope.

KEYWORDS: education, challenges, threats, education for safety

${ }^{1}$ Siedlce University of Natural Sciences and Humanities; Poland. 


\section{WPROWADZENIE}

Bezpieczeństwo jest nierozerwalnie związane z życiem i rozwojem człowieka jako jednostki, z dziejami społeczeństwa, narodów i państw. We współczesnych czasach również jest wartością najwyższą. Jest przedmiotem zainteresowania społecznego zwłaszcza polityków, wojskowych, pracowników nauki, politologów, nauczycieli i psychologów oraz wielu innych badaczy zajmujących się ludzką egzystencją i dobrostanem człowieka. Bezpieczeństwo określa się szczególnie ważną ,potrzebą egzystencjalną człowieka” wynikającą z obiektywnych warunków bytowania ludzi i różnych grup społecznych oraz ich wzajemnych relacji wymagającą troski o jej zaspokojenie”21,2. „Bezpieczeństwo jest pojęciem odzwierciedlającym brak zagrożeń i jego odczuciem; to również zdolność narodu do obrony jego wewnętrznych wartości przed zewnętrznymi zagrożeniami; współczesny miernik szans przetrwania i rozwoju państwa, społeczeństwa oraz jego obywateli"2.

Wielu współczesnych pracowników nauki traktuje bezpieczeństwo jako element życia społecznego i łączy je z bezpieczeństwem osobistym oraz publicznym. Mając na uwadze współczesne wyzwania i zagrożenia warunkujące bezpieczeństwo możemy wyodrębnić zasadnicze potrzeby społeczeństwa $\mathrm{w}$ dziedzinie bezpieczeństwa personalnego i strukturalnego. W tym celu zasadny wydaje się podział zaproponowany przez W. Kitlera, który wyodrębnia dwa obszary, a mianowicie:

- społeczeństwo funkcjonujące w państwie i oczekujące, że zapewnione mu będą potrzeby bytu i rozwoju, a rzeczone państwo może być narażone na różnego rodzaju zagrożenia, sytuacje kryzowe, spowodowane czynnikami politycznymi, społecznymi czy kulturowymi;

- „trudy dnia codziennego”, które należy rozumieć w ten sposób, że ludzie narażeni są na zgubne skutki rozwoju cywilizacyjnego, działalności przestępczej, klęsk żywiołowych lub krócej: „,negatywnej działalności człowieka” bądź „działania sił natury”2 .

\section{EDUKACJA NA RZECZ BEZPIECZEŃSTWA}

Rozważania naukowe wymagają określenia, z czym należy utożsamiać edukację na rzecz bezpieczeństwa odwołując się do istniejącego dorobku naukowego. Studiując bowiem literaturę dotyczącą przygotowania ludności na rzecz bezpieczeństwa, spotykamy się z takimi terminami, jak: „wychowanie obronne”, „wychowanie dla bezpieczeństwa”, „edukacja obronna” czy też „edukacja dla bezpieczeństwa”. Terminy te identyfikowane są ze sobą i często są utożsamiane z edukacją militarną, paramilitarną czy też współdziałaniem z siłami zbrojnymi. Jednak od początku lat 90. dyskusje i badania na temat edukacji dotyczącej bezpieczeństwa

\footnotetext{
${ }^{1}$ J. Kukułka, Bezpieczeństwo a wspótpraca europejska. Wspótzależność i sprzeczność interesów, „Sprawy Międzynarodowe" 1982, nr 7, s.32

${ }^{2}$ J. Kunikowski, Wiedza i edukacja dla bezpieczeństwa, Warszawa 2002, s.165.

${ }^{3}$ W. Kitler, Istota bezpieczeństwa narodowego, [w:] B. Wiśniewski. W. Fehler (red.), Edukacja obronna spoteczeństwa, Białystok 2006, s. 22.
} 
wskazały konieczność uwolnienia się od takiego rozumienia tej działalności, która ogranicza się jedynie do zagrożeń militarnych. Było to efektem odejścia od klasycznego myślenia o zagrożeniach militarnych, uświadamiającym, że troska o bezpieczeństwo nie może należeć wyłącznie do państwa. Jest to nawet niemożliwe, instytucje publiczne i samorządowe nie są bowiem w stanie „,bez wsparcia społecznego zapewnić bezpieczeństwa w każdym z obszarów, tym bardziej że bezpieczeństwo jest egzystencjalną wartością i potrzebą każdego człowieka i dlatego wszyscy są odpowiedzialni za jego tworzenie i pomnażanie"4.

Termin „obronność” jest zdefiniowany w sposób bardzo ogólny, jako „przeciwdziałanie wszelkiego rodzaju zagrożeniom" ", jednak stanowi to przesłankę do tego, aby interpretować edukację na rzecz bezpieczeństwa jako wszechstronną edukację wszystkich podmiotów państwowych, w tym społeczeństwa, które współtworzy państwo. Powyższe rozumienie ukazuje, jak szerokie spektrum działań może się mieścić w ramach edukacji społeczeństwa w interesującym nas obszarze, po to, aby zapewnić możliwość istnienia, przetrwania i rozwoju. A zatem sposób myślenia o bezpieczeństwie przekłada się automatycznie na to, jak jest interpretowana obronność, a także na umiejętności praktycznego działania służącego zapewnieniu bezpieczeństwa ${ }^{6}$. Z takim postrzeganiem zagadnienia koresponduje koncepcja strategiczna NATO. Myślenie szerokie, w kontekście omawianej w niniejszej pracy problematyki, możemy również uzasadnić faktem, że obrona narodowa nie tylko traktuje o działaniach zmierzających do odparcia agresji zbrojnej, lecz także uwzględnia ,sumę wszystkich poczynań militarnych (wojskowych) i cywilnych państwa, mających na celu przeciwdziałanie zagrożeniom bezpieczeństwa kraju (państwa jako podmiotu stosunków międzynarodowych) i społeczeństwa"7. Takie spojrzenie wśród badaczy problemu pojawiało się dawno, o czym może świadczyć stwierdzenie W. Stankiewicza: „działanie obronne jest to świadome zachowanie się społeczeństwa, zmierzające do tworzenia oraz wykorzystania potencjału obronnego w czasie pokoju, zagrożenia i wojny"».

\section{WYZWANIA EDUKACJI DLA BEZPIECZEŃSTWA}

To, co niesie nowoczesna cywilizacja, uświadamia nam, że musimy postrzegać bezpieczeństwo, zagrożenia, a także przysposobienie obronne społeczeństwa do czekających na nie zarówno starych (już znanych), jak i nowych wyzwań w sposób kompleksowy, według zasady naczyń połączonych. Jest to spowodowane między innymi faktem, że zagrożenia nie występują w czystej postaci, albowiem przenikają się wzajemnie. Celem niniejszego opracowania jest zatem próba identyfikacji współczesnych obszarów wyzwań mieszczących się w zakresie oddziaływań edukacji dla bezpieczeństwa.

\footnotetext{
${ }^{4}$ R. Jakubczak, A. Skrabacz, Społeczeństwo w tworzeniu bezpieczeństwa narodowego Polski XXI wieku, Siedlce 2006, s. 138.

${ }^{5}$ Zob.: B. Balcerowicz (red.). Słownik terminów z zakresy bezpieczeństwa narodowego, Warszawa 2001.

${ }^{6}$ M. Cieślarczyk, Kultura bezpieczeństwa i obronności, Siedlce 2006, s. 126-127.

7 Tamże, s. 128.

${ }^{8}$ W. Stankiewicz, Planowanie obronne, Warszawa 1977, s. 15.
} 
Edukację dla bezpieczeństwa można rozpatrywać również na innych płaszczyznach poznawczych. T. Jemioło twierdzi, że utożsamianie tej edukacji wyłącznie z czasem kryzysu i wojny musi budzić duże wątpliwości „,...) nie tylko z powodu swej jednostronności, ale także wobec dążeń do pokoju na świecie - dążeń osobliwych dla cywilizacji zachodu”. Określa więc paradygmat jako wychowanie dla bezpieczeństwa, „które pozwala wywodzić go z rozpoznania natury ludzkiej i jej uniwersalnych dążeń. Tymi dążeniami i pragnieniami, wymienionymi razem po raz pierwszy przez Platona i odtąd utrzymującymi się w naszej kulturze jest Prawda, Dobro i Sprawiedliwość"

W procesie edukacji na rzecz bezpieczeństwa powinno się uwzględniać wolność jednostki, niwelując w trakcie tego procesu aspekty ideologiczne i polityczne - dążenia, które odnoszą się do, wspomnianych wyżej, wymienionych wartości uniwersalnych.

Przyjmując wspomniany paradygmat wychowania dla bezpieczeństwa, edukacja dla bezpieczeństwa nie odnosi się tylko do przeciwdziałania zagrożeniom, lecz także, co wydaje się bardzo istotne, dotyczy wyzwań mogących stać się zagrożeniami. Takiego wyróżnienia dokonał T. Jemioło, który tym samym wskazał, że edukacja obronna i edukacja dla bezpieczeństwa się pokrywają, jeżeli chodzi o zakres znaczeniowy, jednak terminy te nie są identyczne. Takie ujęcie wydaje się obecnie koniecznością. Jest to związane $z$ wieloma procesami i zjawiskami, do których możemy zaliczyć pluralizm kulturowy czy też globalizację. W związku z tym, jak zauważa T. Jemioło, aby sprostać współczesnym wymaganiom, niewątpliwie wiążącym się z kształtowaniem i tworzeniem, w celu zachowania, swojej podmiotowości (bezpieczeństwa), konieczne są aktywność, zaangażowanie oraz „(...) walki i wojny, jeżeli chcemy przetrwać, przeżyć, chronić nasze rodziny, zwalczać nasze choroby" ${ }^{\prime 10}$.

Niewątpliwie współczesnym wyzwaniem jest pewna transformacja w myśleniu o bezpieczeństwie, jego podmiotowym wymiarze, a także przenikanie się poszczególnych wymiarów tego bezpieczeństwa. Można zauważyć, w jaki sposób wskazanie wielu autorów publikacji poświęconych tej problematyce, szerokie myślenie o bezpieczeństwie może powodować, że któryś z wymiarów gdzieś zaginie w świadomości społecznej. Wspomniana zasada wahadła może doprowadzić w konsekwencji do zaniedbania w danym wymiarze podmiotowym. Tym samym należałoby myśleć nie tylko poprzez to, co „tu” i „teraz”, ale również poprzez pewne wyzwania o charakterze perspektywicznym.

Powstaje w tym miejscu pytanie o to, jakie działania powinny mieścić się w ramach edukacji na rzecz bezpieczeństwa. Jeżeli ta edukacja ma odnosić się do wszystkich zagrożeń, w tym także do czekających nas wyzwań, szczególne znaczenie będą mieć związki i zależności między edukacją dla bezpieczeństwa a innymi rodzajami edukacji. Należy zaznaczyć w tym miejscu, że edukacja dla bezpieczeństwa zawiera komponenty zarówno dydaktyczne, jak i wychowawcze.

\footnotetext{
${ }^{9}$ T. Jemioło, Edukacja obronna w świetle strategii bezpieczeństwa, [w:] E.A Wesołowska, A. Szerauc (red.), Patriotyzm, obronność, bezpieczeństwo, Warszawa 2002, s. 167-168.

${ }^{10}$ Tamże, s. 167.
} 
Potwierdzenie tego faktu odnajdujemy w literaturze przedmiotu ${ }^{11}$. A zatem za zasadne uznać należy używanie terminu „edukacja” czy też odwoływanie się do niego. Ponadto istotą edukacji dla bezpieczeństwa jest szerzenie świadomości i wiedzy o źródłach, rodzajach i następstwach zagrożeń, z jakim możemy się spotkać zarówno w życiu codziennym, jak i sytuacjach wyjątkowych. Będzie mieścić się tu również umiejętność rozpoznawania, zapobiegania i eliminowania powstałych zagrożeń oraz gotowość i umiejętność niesienia pomocy.

Ze względu na powyższe aspekty edukacją dla bezpieczeństwa należy objąć całe społeczeństwo w celu lepszego zrozumienia tego, co jest obecnie, oraz tego, co będzie w przyszłości. Mając na uwadze powyższy punkt widzenia, należy przygotowywać społeczeństwo pod względem merytorycznym, z jednoczesnym przygotowaniem psychologicznym, ${ }^{12}$ rozwijając kulturę bezpieczeństwa, aktywność społeczną w obszarze współtworzenia i współorganizowania bezpieczeństwa narodowego na każdym szczeblu - począwszy od narodowego, poprzez lokalny, a skończywszy na poziomie indywidualnym. Zaspokojenie takich potrzeb istnienia, integralności, całości niezależności, posiadania i możliwości rozwoju wymaga działania nie tylko wyspecjalizowanych służb do tego przygotowanych, lecz także całego społeczeństwa.

Jednym ze sposobów kształtowania środowiska bezpieczeństwa personalnego i strukturalnego jest proces edukacji, który poprzez świadome i planowe działanie ma na celu wpływanie na postawy, system wartości i wreszcie wiadomości i umiejętności konieczne do zapobiegania skutkom zagrożeń, ich niwelowania i usuwania ${ }^{13}$.

Niewątpliwie rozważaniom na temat edukacji na rzecz bezpieczeństwa muszą towarzyszyć refleksje na temat współczesnych jego uwarunkowań. Nowe rodzaje zagrożeń, dynamika współczesnego świata, a w związku z tym konieczność spojrzenia perspektywicznego stanowią punkt wyjścia do zdefiniowania, czym powinno być rzeczone przygotowanie, tak aby było skuteczne i na miarę wyzwań.

W sensie ogólnym uwzględniając nowe wyzwania, szanse i zagrożenia oraz sposób myślenia o bezpieczeństwie i obronności, edukacja dla bezpieczeństwa dotyczy działania mającego na celu wyposażenie społeczeństwa w wiadomości i umiejętności, a także kształtowanie systemu wartości. Czynności te doprowadzają do rozpoznawania wyzwań, szans i zagrożeń, przeciwdziałania konsekwencjom zagrożeń ważnych dla bezpieczeństwa indywidualnego, społecznego, bezpieczeństwa narodowego i ich minimalizowania.

Tak rozumiana edukacja na rzecz bezpieczeństwa dotyczy następujących obszarów:

- warstwa aksjologiczna: kształtowanie postaw, hierarchii wartości, więzi społecznych i odpowiedzialności za sprawy związane z obronnością na rzecz sprostania wyzwaniom i zagrożeniom wynikającym z rozwoju cywilizacyjnego, ze strony sił przyrody, a także wojny;

\footnotetext{
${ }^{11}$ Zob.: J. Kunikowski (red.), Przygotowanie obronne społeczeństwa, Warszawa 2001.

12 Tamże, s. 191-195.

${ }^{13}$ G. Adamczyk, S. Rutecki, Strukturalne i treściowe uwarunkowania edukacji obronnej młodzieży szkolnej i akademickiej, [w:] R. Stępień (red.), Współczesne zagadnienia edukacji dla bezpieczeństwa, Warszawa 1999, s. $192-194$.
} 
- warstwa poznawcza i reguły postępowania: przygotowywanie społeczeństwa jako całości wraz z ,(...) wyspecjalizowanymi strukturami do działalności praktycznej poprzez zapewnienie stosownych instrumentów prawnych i mechanizmów pozwalających wszystkim szczeblom władzy, organizacjom pozarządowym i instytucjom humanitarnym szybko i skutecznie działać, by w efekcie zapobiegać, minimalizować i usuwać skutki zagrożeń militarnych i innych występujących w czasie pokoju"14;

- wyposażenie społeczeństwa w wiadomości i umiejętności potrzebne do powszechnej obrony ${ }^{15}$. Edukacja dla bezpieczeństwa społeczeństwa powinna być również zróżnicowana pod względem celów, treści, form i metod. Podejście holistyczne wymaga wyszczególnienia trzech poziomów tej działalności, a mianowicie: podstawowego, specjalistycznego i wyższego. W związku z tym w ramach przygotowania obronnego społeczeństwa należy uwzględniać obszary z zakresu filozofii i historii, edukacji ratowniczej, zdrowotnej, ekologicznej, przeciwprzestępczej i wojskowej.

\section{Podsumowanie}

Edukacja dla bezpieczeństwa wiąże się z przygotowaniem wszystkich obywateli do skutecznego realizowania zadań związanych $\mathrm{z}$ przeciwstawianiem się zagrożeniom zarówno w okresie działań orężnych i kryzysowych, jak i w czasie pokoju.

Ludzie, poprzez zdobywanie coraz to nowych doświadczeń i podnoszenie poziomu swojej wiedzy w zakresie szeroko pojmowanego bezpieczeństwa, potrafią w taki sposób modyfikować zachowania, aby odpowiednio działać w różnych, często nowych sytuacjach, które wymagają niekonwencjonalnego myślenia i skutecznego działania w sytuacjach zagrożeń. Współcześnie, gdy odpowiednia reakcja na sytuację kryzysową jest często jedyną szansą przeżycia, ważne jest to, aby każdy człowiek zdobywał jak najwięcej wiedzy i umiejętności, dzięki którym będzie potrafił tak zareagować, oraz to, by ci, którzy już potrafią odpowiednio reagować, umiejętnie przekazywali tę wiedzę innym. Ponieważ człowiek nie jest w stanie wyeliminować wszystkich zagrożeń i na nie reagować, skutecznym działaniem będzie próba zapobiegania niektórym z nich i ich skutkom. Zapobieganie jest najtańszym i najbardziej efektywnym sposobem radzenia sobie z zagrożeniami. Można to osiągnąć dzięki edukacji całego społeczeństwa w zakresie bezpieczeństwa.

Przezorność i zapobiegliwość nie należą do najmocniejszych stron społeczeństwa. Ludzie bardzo często nie są w stanie dostrzec potencjalnych zagrożeń, szans i wyzwań dnia codziennego. Doprowadza to w konsekwencji do tego, że gubią się w trudnych sytuacjach kryzysowych, jakie niesie rzeczywistość, np. w przypadku przyrodniczych zagrożeń ${ }^{17}$.

Aby żyć bezpiecznie, należy przestrzegać głównych zasad, do których należą:

\footnotetext{
${ }^{14}$ M. Kucharski, Edukacja obronna, Warszawa 2002, s. 151.

15 Tamże, s. 151.

${ }^{17}$ Wymownym tego przykładem jest powódź w południowej - zachodniej Polsce z 1997 roku i południowej części Podlasia z 2006 roku.
} 
- przewidywanie niebezpieczeństw,

- stosowanie działań zapobiegawczych,

- gotowość na wyzwania czasów pokoju i wojny,

- umiejętność reagowania w sytuacjach zagrożeń.

Aby zapobiec niebezpieczeństwu, niezbędna jest znajomość własnej psychiki i możliwości fizycznych. Człowiek w krytycznych sytuacjach zdolny jest do pokonania strachu i uruchomienia dodatkowych zasobów energii „w nim drzemiących”. Jeśli znamy potencjalne źródła zagrożeń i sposoby ich unikania, stanowi to ważną predyspozycję, która pozwoli sprostać tym zagrożeniom. Świadomość tego daje człowiekowi poczucie bezpieczeństwa. Dużymi błędami są jednak przecenianie własnych umiejętności, zbytnia pewność siebie, brawura, bezmyślność i nierozwaga.

W ramach zapobiegania zagrożeniom najlepszym rozwiązaniem zdaje się edukacja dla bezpieczeństwa całego społeczeństwa, a zwłaszcza młodzieży szkolnej. Chodzi bowiem nie tylko o wszechstronne przygotowanie do życia, lecz także o zdobywanie umiejętności, dzięki którym można zapewnić bezpieczeństwo sobie i otoczeniu.

Człowiek najczęściej generuje zagrożenia, gdyż nie przestrzega podstawowych zasad bezpieczeństwa, nie dostrzega odpowiednio znaków ostrzegawczych, zachowuje się bezmyślnie, naiwnie i nieostrożnie, zbytnio ufa wrażliwości i dobrym intencjom innych, nie zachowując należytej czujności. Funkcjonuje obiegowe stwierdzenie, że nieszczęścia zdarzają się innym, nie nam. Takie myślenie może okazać się dla nas bardzo zgubne, iluzoryczne. Z historii najnowszej znamy przykłady iluzji odporności, prowadzące do katastrofalnych skutków zaniedbań. W rzeczywistości mamy do czynienia z nieprzewidywalnością zdarzeń regionalnych (np. dokuczliwe klęski żywiołowe) współczesnego świata, co stanowi istotny argument, aby angażować społeczeństwo w problematykę bezpieczeństwa, zarówno lokalnego, jak i państwowego.

Każda ekstremalna sytuacja wymaga nieschematycznego (i twórczego) myślenia oraz działania. Każda jest inna i nie ma na nią gotowych schematów postępowania. Należy jednak pamiętać o pewnych zasadach, dzięki którym łatwiej możemy „przetrwać” daną sytuację kryzysową. Należy wtedy:

- zapoznać się z istotnymi faktami i zebrać jak najwięcej informacji związanych z określoną sytuacją,

- nie ulegać panice,

- w jak najbardziej logiczny sposób spróbować zanalizować zastaną sytuację,

- ustalić priorytety zadań do wykonania,

- podjąć decyzję o działaniu,

- zacząć działać w sposób stanowczy (asertywny), bez oglądania się wstecz.

Postępując w ten właśnie sposób, możemy znacznie zmniejszyć następstwa zagrożeń. Powyższe reguły myślenia i działania pomogą nam zachować zdrowie i życie, a także dzięki nim możemy udzielić pomocy innym ludziom. 
Przyjęcie właściwej postawy obronnej umożliwia stawienie czoła przeciwnościom losu, różnym zagrożeniom życia codziennego, klęskom żywiołowym czy skażeniom środowiska naturalnego. Jednakże żyć bezpiecznie to nie tylko być przezornym i zapobiegawczym, lecz także zmieniać przyzwyczajenia i głęboko tkwiące w nas nawyki. To również wyrzekanie się pewnych wygód i akceptowanie bardziej surowej dyscypliny. By „zmienić świat”, zacznijmy od „zmiany samych siebie”, choć podobno człowieka nie da się zmienić - można go jedynie ulepszyć.

Dzięki wiedzy i umiejętnościom, jakie społeczeństwo zdobywa poprzez edukację na rzecz bezpieczeństwa, stanie się ono świadome otaczającej je rzeczywistości, spraw dotyczących bezpieczeństwa i obronności oraz procesów zachodzących zarówno w tej rzeczywistości, jak i w samym społeczeństwie (także w spojrzeniu indywidualnym na każdą jednostkę). To z kolei przyczyni się do podniesienia stanu bezpieczeństwa jednostki, społeczeństw i narodu oraz do wzrostu świadomości społeczeństwa w zakresie bezpieczeństwa i obronności.

Tak więc uwzględniając wymienione już uwarunkowania postrzegania obronności w odniesieniu do wszelkiego rodzaju zagrożeń, a także potrzebę postrzegania niektórych zdarzeń w kategoriach wyzwań, nie ograniczają się do rozumienia edukacji na rzecz bezpieczeństwa jedynie w kontekście istniejących już zagrożeń.

\section{BIBLIOGRAFIA}

Araucz-Boruc Agnieszka. 2015. Bezpieczeństwo i obronność w edukacji młodzieży. Siedlce: Wydawnictwo Uniwersytetu Przyrodniczo-Humanistycznego.

Araucz-Boruc Agnieszka. 2019. "Preparation of young people in Poland to operate in dangerous situations as an element of national security system". De Securitate et Defensione. O Bezpieczeństwie i Obronności 1(5): 144-154. https://doi.org/10.34739/dsd.2019.01.11

Balcerowicz Bolesław (red.). 2001. Słownik terminów z zakresy bezpieczeństwa narodowego. Warszawa: Akademia Obrony Narodowej.

Bielawski Kornel. Znaczenie edukacji dla bezpieczeństwa we współczesnym społeczeństwie. (google scholar)

Cieślarczyk Marian. 2006. Kultura bezpieczeństwa i obronności. Siedlce: Wydawnictwo Akademii Podlaskiej.

Fehler Włodzimierz, Wiśniewski Bernard (red.). 2006. Edukacja obronna społeczeństwa. Białystok: Wydawnictwo Niepaństwowej Wyższej Szkoły Pedagogicznej.

Grabowska-Lepczak Izabella, Tryboń Monika, Kwiatkowski Marek. 2011. „Transformacja oraz perspektywy rozwoju edukacji dla bezpieczeństwa w Polsce". Zeszyty Naukowe SGSP 2011/41: 181-190.

Jakubczak Ryszard. Skrabacz Aleksandra. 2006. Społeczeństwo w tworzeniu bezpieczeństwa narodowego Polski XXI wieku. Siedlce: Wydawnictwo Akademii Podlaskiej.

Kucharski Marek. 2002. Edukacja obronna. Warszawa: Fundacja Innowacja.

Kukułka Józef. 1982. „Bezpieczeństwo a współpraca europejska. Współzależność i sprzeczność interesów”. Sprawy Międzynarodowe 7: 7-22. 
Kunikowski Jerzy (red.). 2001. Przygotowanie obronne społeczeństwa. Warszawa: Dom Wydawniczy Bellona.

Kunikowski Jerzy. 2002. Wiedza i edukacja dla bezpieczeństwa. Warszawa: Fundacja Rozwoju Edukacji Europejskiej i Bezpieczeństw.

Kwiasowaki Zbigniew, Cenda-Miedzińska Klaudia (red.). 2012. Edukacja dla bezpieczeństwa wobec wyzwań współczesności. Kraków: Wydawnictwo Naukowe Uniwersytetu Pedagogicznego.

Łukawska Marta. 2016. „Edukacja jako jeden z gwarantów bezpieczeństwa w Polsce”. De Securitate et Defensione. O Bezpieczeństwie i Obronności 2(2): 144-154.

Richter Manfred. 2019. "Education - To Which Ends, for Which Goals? Comenius Answers: Self-Command, Irenism (Ecumenism), World Peace [Edukacja i jej cele? Dlaczego nauczamy? Edukacja - jej cele i zadania. Odpowiedzi Komenskiego: samokontrola, irenizm (ekumenizm), swiatowy pokój]”. Rocznik Teologiczny 3: 565-578.

Siuda Tadeusz (red.). 2007. Kształcenie i wychowanie młodzieży na rzecz bezpieczeństwa. Warszawa: Oficyna Wydawniczo-Poligraficzna „ADAM”.

Stankiewicz Tomasz. 1977. Planowanie obronne. Warszawa: MON.

Stępień Ryszard (red.). 1999. Współczesne zagadnienia edukacji dla bezpieczeństwa. Warszawa: AON.

Wesołowska Eugenia, Szerauc Anna (red.). 2002. Patriotyzm, obronność, bezpieczeństwo. Warszawa: Akademia Obrony Narodowej, Płock: Szkoła Wyższa im. Pawła Włodkowica. 